\author{
Удк 355.01"20" \\ DOI: https://doi.org/10.18485/fb_iss.2020.1.ch2
}

\title{
РАТОВИ 21. ВЕКА И КЛАСИЧНА СТРАТЕГИЈСКА МИСАО
}

\author{
проф. др Станислав Стојановић 1
}

\section{Апстракт}

Драматичне промене које се одвијају у теорији и пракси савремених оружаних сукоба, посебно њихова комплексност и широк спектар манифестовања и њихов све израженији асиметрични, хибридни и мрежноцентрични карактер, сугеришу да је реч о новим ратовима, различитим од свих ранијих. Најрадикалнији изрази трансформације рата који су иницирани променама постиндустријске реалности представља идеја мреже која почива на коеволуцији информационих технологија, економије, пословних процеса и организације. Мрежноцентрична парадигма је примарно усмерена на експлоатацију домета технолошке супериорности, она измешта средиште савремених оружаних сукоба изван физичког домена, а функционисање борбених састава постаје засновано на принципима брзине и самосинхронизације, који омогућавају да се види, оријентише и делује пре противника. Истовремено, асиметричност као најзначајнија обележје промена политичког, економског и социјалног миљеа живота савремених људи, представља и парадигматско обележје савременог безбедносног окружења и оружаних сукоба који се данас воде. Све израженији асоцијалан контекст глобалних процеса, пре свега њихов наглашен транснационални карактер, чини социјални оквир појаве снажних и непредвидивих асиметричних угрожавања безбедности савремених друштава. Наравно, континуитет реалполитичких образаца у међународној политици и отворено геополитичко надметање, а још чешће прикривено деловање најмоћнијих држава света, као и других недржавних актера, интензивирали су појаву хибридних оружаних сукоба, чија збуњујућа физиономија на нови начин потенцира синергијски приступ у интеграцији свих инструмената државне моћи, стављајући у први план невојне и нерегуларне садржаје. Ова специфична, садржајно и методски неухватљива врста ратова, посебно када је реч о мотивима, циљевима и начинима деловања, упућује на њихову утемељеност на својственом стратешком приступу, стављајући на озбиљна искушења класичну стратегијску мисао и праксу вођења рата. Актуелизована су бројна питања о суштини ратова и начинима на које се они воде, доводећи у питање одрживост неких од носећих постулата класичне

1 Ванредни професор, Универзитет одбране, Институт за стратегијска истраживања. Епошта: stanislav.stojanovic@mod.gov.rs 
стратегијске мисли и Калузевица као једног од њених најзначајнијих утемељивача. Не спорећи да су ратови 21. века по многим својим обележјима аутентични, полазно теоријско становиште аутора овог рада јесте да је класична стратегијска мисао и даље релевантна и валидна теорија и да је незаобилазна у креирању стратешких способности савремених цивилних лидера и војних стратега.

Кључне речи: нови ратови, мрежноцентрични рат, асиметрични рат, класична стратегија

\section{УВОД}

Тешко је оспорити чињеницу да живимо у времену када су најзначајнији аспекти безбедности стављени на озбиљна искушења, а савремени свет квалификује се као опасан и непредвидив. Бројни и наглашени деконструктивни глобални процеси радикализовали су стратегијско окружење, заоштривши бројне цивилизацијске, идентитетске, идеолошке и геополитичке искључивости и анимозитете. Тако профилисани процеси су критично повећали елементе неизвесности и конфликтности у свету. Показало се да нова цивилизација у многим аспектима није избегла опасности застрашујућих неједнакости, геополитичких надметања и идеолошке искључивости ${ }^{2}$. Такве околности одлучујуће утичу на чињеницу да ратови и даље врло значајно обликују токове међународне политике.

Друга половина двадесетог, а посебно почетак двадесет првог века, представљају периоде револуционарних промена реалности савременог света. Изузетни технолошки продори отворили су просторе за радикално нове садржаје социјалног живота људи, мењајући из основа обрасце њихове индивидуалне и колективне егзистенције. Истовремено, технолошки прогрес је драматично реконфигурисао форму и садржаје савремених оружаних сукоба.

Снажна трансформација савремених оружаних сукоба допринела је томе да се они тешко могу упоредити са раније вођеним оружаним сукобима у политичкој историји света. Управо зато се у стручној и академској јавности појавио велики број различитих термина којим се именују савремени оружани сукоби, попут: постмодерни, постнационални, ирегуларни, асиметрични, хибридни, прокси, нетројствени рат. Све то је покренуло бројне расправе о томе колико су и у којој мери савремени глобални процеси изменили природу рата и да ли су и даље одрживи неки од носећих постулата класичне стратегијске мисли.

\footnotetext{
2 Станислав Стојановић, Ксенија Ђуериић Атанасиевскинас, „Дефицити и ограничења глобалног управљања“, Српска политичка мисао, Београд, 2/2016.
} 


\section{ТРАНСФОРМАЦИЈА РАТА}

Рат је одувек био одраз свога времена са свим својим посебностима и увек је носио обележја датог временског раздобља. Особеност политичких, економских и културолошких односа, нарочито технолошки домети четврте технолошке револуције су фактори који су одлучујуће утицали на форму и садржаје савремених оружаних сукоба.

Наглашена амбивалентност глобалних процеса, посебно наметљиво промовисање једног политичког, економског и, надасве, културолошког обрасца, оспорили су идеју о глобалном зближавању света, чиме је креиран глобални миље у коме су идентитетска и друга одређења добила примат. Последице тога били су радикализацаја анамиозитета и мноштво врло различитих оружаних сукоба који су показивали дотле незабележену особеност. Покренуте су дебате и теоријске расправе о аутентичној природи оружаних сукоба у постиндустријском друштву, посебно ако је очигледно да рат као борба на бојном пољу, рат као масовни и одлучујући догађај у међународном спору, све мање постоји. ${ }^{3}$

Питања рата која се тичу његових актера, услова, узрока, циљева и њихових концепта јесу питања чије разматрање обезбеђује у садржајном смислу суштинске одговоре о карактеру и најзначајнијим одређењима рата. Другим речима, одговори на питања ко води рат, зашто се он води, због чега се води, и о начинима на који се он води, омогућавају сагледавање тога шта су и у коликој мери ново донели ратови 21. века. ${ }^{4}$ Заправо, одговори на та питања треба да потврде да ли је асиметричност, као концепт који је актуелизовао стратешке мањкавости моћних конвенционалних армија са бројчано далеко инфериорнијим противницима, поред хибридности, која је проширила спектар сукоба, и мрежноцентричности, која симболизује највише домете технолошке супериорности, представљају нове ратове.

Више него икада, рат постмодерног доба је одраз друштвених, пре свега економских односа, као и фасцинантних домета четврте технолошке револуције. Технолошки прогрес је све параметре ратовања - брзину, домет и прецизност довео до крајњих граница. Јасно је да примена нових технолошких открића има прворазредно место у обликовању савремених оружаних сукоба и да технологија представља важну претпоставку унапређења способности оружаних састава. 5 Напредне информационе и друге технологије револуционишу војну делатност, борбени простор и стратегијско окружење.

Информатизација, интелигентизација, паметно оружје, аутономни борбени системи и роботи, који све значајније мењају праве војнике, беспилотне летилице

3 Ruper Smith, The Utility of Force The Art of War in the Modern World , A. Konpf Book, New York, 2007, p13.

4 Мартин Ван Кревелд, Трансформација рата , ЈП, Службени гласник, Факултет безбедности, Београд, 2010, стр 11.

5 Leonid Savin, Koučing ratovanja, Beograd, 2019. 
са најразличитијим перформансама и конфигурацијама, укључујући и микролетелице, чине преовлађујуће трендове који реконфигуришу савремене војске и начине њихове борбене употребе, ширећи домен конфликта сукобљених страна у сајбер-простор и космос. ${ }^{6}$ Наравно, у контексту будућности анализирају се пројекције војника будућности и место бионанотехнологије, неуропротеза, специјалне исхране војника, компјутерских игрица и виртуелних симулатора борбених операција.

На делу су бројне стратегијске, концептуалне и структурне промене у ОС, пре свега модернизација војне опреме и борбених система, модернизовање организације снага. Оперативни концепти у фокусу имају интегрисаност и милтидимензионалност употребе оружаних снага у условима константног надметања и брзих промена. Јасно је да савремене оружане снаге све чешће представљају мешавину посадних, беспосадних и аутономних борбених система. Истовремено, потпуно обједињавање свих нивоа ОС - стратешког, оперативног и тактичког - у једну целину са осталим друштвеним структурама претпоставка је успеха у савременим оружаним сукобима, модернизацији опреме и организацији снага.

Рат као међудржавни сукоб је изгубио на значају јер насиље све више практикују актери који не долазе из државних оквира, што нарушава монопол државе у демонстрирању силе као суштинском одређењу државе. Држава је изгубила ексклузивитет вођења рата. Децентрализација способности за организовано насиље и мноштво нових недржавних актера и експлозивни потенцијал политичких и идентитетских мотива за провоцирање сукоба.

Истовремено, рат, а посебно онај конвенционални, све више постаје неефикасан као инструмент политике, изазивајући фрустрирајућа осећања о застарелости класичне војне силе. Конвенционална војна сила не показује пуну делотворност и често је очита њена неефикасност. Данас највећа моћ није истовремено и најбоља стратегија, а квантум војне моћи није оно што доводи до победе или крајњег циља у рату. Проблематизована је класична дефиниција војне победе, а улога невојних садржаја на крајњи исход рата поприма сасвим нове димензије. Ратови показују тенденцију ка неборбеним операцијама а савремени центар гравитације ближи је критичним способностима.

У свеобухватном карактеру рата војна средства све ређе су решавајући садржаји и често су само додатак широком списку невојних метода и инструмената који се практикују у достизању пројектованих ратних циљева. Јасно је да у постмодерним ратовима, употреба физичког насиља губи примат у односу на употребу менталног. На овакав закључак недвосмислено наводе мишљења појединих теоретичара и аналитичара рата који уочавају да је примена физичке силе није пресудна у савременим сукобима, и сматрају да њена употреба често није ни нужна.

6 Видети више у: Srđan T.Korać, Disciplinsko ratovanje u doba dronova i robota , IMPP, Beograd, 2019. 
Синергијски приступ афирмацији војне моћи указују на пораст компоненти на којима се темељи савремено ратовање. Управо зато модел савременог ратовања нужно обухвата политичке, економске, правне, етничке, верске, социјалне и технолошке компоненте, а разумевање свих ових фактора и природе њихових међусобних односа могу бити основа за предност у будућим сукобима.

Постоји снажно уверење да технолошки развој подстиче пацификацију средстава за вођење рата, апострофирајући креативност као основ успеха у рату, што значи да су победе и порази рођени у уму. Отуда, постмодерни концепт рата фокусиран је на људски ум, па ако желите да непријатељеву вољу уништите кинетичком енергијом Клаузевицеве војне силе, осуђени сте на неуспех. Наиме, јавила су се мишљења да је будућност рата усмерена на вођење сукоба ка субординацији противника без насиља, што је и најзахтевнија врста рата, она која позива на његов најкреативнији модел. Зато је когнитивни домен све значајнији елемент у комплексној структури нових оружаних снага, концепцији и технологији.

У корпус оваквих револуционарних мишљења може се сврстати и оно према коме технолошки развој доводи до пацификације средстава вођења рата и да ће се у будућности водити ратови попут тзв. мрежних ратова, који неће садржати физичко већ ментално насиље у имагинарној, информационој димензији.

\section{АСИМЕТРИЧНИ, МРЕЖНИ И ХИБРИДНИ РАТОВИ}

Радикална промена најзначајнијих детерминанти политичког, економског и социјалног живота савремених људи у 21. веку, фасцинантни технолошки напредак и амбивалентни глобални процеси, подстакли су појаву нових форми оружаних сукоба који на значајно нови начин угрожавају безбедност савремених друштава. Очигледно је да се актуелни оружани сукоби не одвијају у чистом облику, већ су мешовити или хибридни. У сукобима егзистирају механика метка, термодинамика експлозија, кибернетика, комуникација и компјутерске технологије.

Измењене друштвене околности, као и спорне способности националних држава да ефикасно штите националне интересе, отвориле су просторе за „демократизацију насиља“ и појаву нових, нетрадиционалних асиметричних форми и актера угрожавања безбедности. Садржај, појавни облици и све мање предвидиви домети асиметричних угрожавања представљају једно од главних обележја процеса који угрожавају савремена друштва. Њихова разноврсност у погледу организованости, циљева, мотива и метода деловања потврђује став да је реч о специфичном стратешком приступу који одрживост темељи на начелима асиметрије. Тако су транснационална динамика постнационалног друштва и наглашена асоцијална природа глобалних процеса учинили да екстремизам, тероризам и организовани криминал, који своју одрживост темеље на начелима симетрије, постану мора савременог света.

Асиметрија снага, стратегије, морала, софистицирана војна опрема и нехијерархијска организација, као и дисолутивни потенцијал асиметричних угрожавања, редефинишу носеће постулате безбедности, ширећи осећај глобалне 
небезбедности. Актери асиметричних угрожавања безбедности дискредитују дуго чувани примат државе као најдоминантнијег, а у одређеним временским епохама и јединог актера безбедности, и својим наглашеним асиметричним обележјима представљају тешко решиву енигму за безбедност савремених друштава. Својим ефектима на глобални пораст небезбедности и несигурности, као и снажним усложњавањем геополитичких надметања кључних актера у савременој међународној политици, носиоци асиметрије наметнули су бројне дилеме у вези са примереношћу традиционалних стратешких приступи као оквира у изналажењу одговора на асиметрично угрожавање безбедности. ${ }^{7}$

Темељећи своју аутентичност и домете на достигнућима информационих технологија, концепт мреже представља једну од најутицајнијих идеја преобликовања друштава у новом миленијуму. Мрежно друштво, које је све значајније почива на нехијерархијским мрежним премисама, умногоме представља предзнак новог, постмодерног друштвеног концепта, укључујући и оружане сукобе и ратове. Идеја мрежа постаје модел трансформације конвенционалних оружаних сукоба, у којима је војна сила оличење физичке силе и кинетичке енергије, смештајући конфликт у физичку, информациону, когнитивну и социјалну сферу. Фокусираност на предности софистициране високе технологије мрежни приступ креира нове димензије надметања, виртуелизује борбени простор и истовремено повећава ватрену моћ, брзину и прецизност деловања, али и увид у реалну ситуацију и командовање у реалном времену.

Мрежноцентрични контекст оружаних сукоба снажно оспорава Њутнову линирану логику на којој Клаузевиц заснива своје учење о рату. Мрежни рат превазилази оквире Клаузевицеве мисли тако што тежиште са физичке надмоћи премешта у сферу дуготрајне контроле у информационој, когнитивној и социјалној сфери. Мрежноцентрични рат је утемељен на новој парадигми економије, чиме се потврђује теза Тофлерових, да начин производње одређује начине ратовања 8 . Тако се рат манифестује као облик конкуренције, па војна делатност и функционисање борбених састава следе принципе бизниса и економије, посебно када је реч о концепту брзине и самосинхронизације, који се сматрају за носеће принципе мрежноцентричног приступа. Теорија пет прстенова, као и петља ООДА, као важни оквир револуције војне делатности, такође следе мрежноцентричну парадигму и примарно су усмерени на домете технолошке супериорности као платформе - видети, оријентисати се, одлучити и деловати пре противника.

Посебну пажњу завређују размишљања у којима се проблематизује традиционална хијерархијска организације оружаних снага и актуелизује значај

7 Станислав Стојановић, Вељко Благојевић, Милован Суботић, Бранислав Милосављевић и Милош Миленковић, Асиметрично угрожавање безбедности на примеру Југоисточне Европе, Медија Центар, Београд, 2019.

8 Алвин и Хајди Тофлер, Рат и анти рат, ПАИДЕА, Београд, 1998. 
хаордичног приступа војној организацији, имајући у виду да хијерархија и контрола ограничавају простор аутономије, слободе и вредности појединца, као основ флексибилност и адаптација оружаних снага у променљивом окружењу paтa. $^{9}$

Трансформација гломазних и релативно статичних војних снага у мање, флексибилне, модуларне и мобилне снаге, уз коришћење престижа техничкотехнолошких могућности структура. Информациона супериорност је у функцији потпуне доминације на борбеном простору, а доктринарне и организационе трансформације су функције пуне експлоатације оружја заснованог на информационим технологијама. Иновативна примена нових технологија у комбинацији са променама војних доктрина фундаментално мења карактер и технологију извођења војних операција. У том смислу, мрежноцентрично ратовање је један од кључева трансформације војне делатности.

Мрежни ратови су постмасовни ратови, у њима количина физичке силе губи значај. Циљ мрежног рата није победа противника у директном сукобу, то је тек мали фрагмент мрежног рата, већ успостављање и одржавање контроле. Другим речима, само оружје више не решава рат, већ настојање да се успостави сопствена мрежа и да се продре у друге мрежне просторе. Мрежни рат превазилази оквире Клаузевицеве мисли тако што тежиште са физичке надмоћи премешта у сферу дуготрајне контроле у информационој, когнитивној и социјалној сфери. Отуда, мрежноцентрични концепт рата фокусиран је на људски ум, па ако желите да непријатељеву вољу уништите кинетичком енергијом Клаузевицеве војне силе, осуђени сте на неуспех. Будућност рата је усмерена на вођење рата ка субординацији противника без насиља, што је и најзахтевнија врста рата која позива на најкреативнији модел рата. Зато је когнитивни домен основни елемент у комплексној структури нових оружаних снага, концепцији и технологији. Подривање монопола државе, информациона контрола, индоктринација учесника и хуманитарне интервенције представљају важне обрасце организационог, доктринарног, социјалног и технолошког нивоа мрежног ратовања.

Комплексна динамика односа у међународној политици, посебно асиметричност, као најзначајније обележје промене глобалног социјалног миљеа, отворено геостратегијско надметање и, још чешће, прикривено деловање сукобљених актера, посебно неделетворност чисте војне силе, представљају оквир настајања збуњујуће хибридне физиономије оружаних сукоба. ${ }^{10}$

Термин хибридно задобија глобалну пажњу у политичким и медијским круговима са почетком кризе у Украјини као упозорење да је западни стил ратовања постао некомпатибилан и фундаментално неусаглашен са реалношћу. Реч је о концепту који је у неким сегментима нејасан и конфузан и са ограниченом аналитичком вредношћу. Концепт у појмовном смислу не нуди ништа револуционарно ново,

\footnotetext{
${ }^{9}$ Leonid Savin, ucmo.

10 Erik Reichborn-Kjennerud ,Patrick Cullen, «What is Hybrid Warfare?», Policy Brief, 1 /2016
} 
посебно ако се зна да хибридност прати одувек праксу вођења ратова. Међутим, нове су технолошке могућности које таквом концепту дају друге димензије, чинећи од њега све заступљенији модел практиковања војних активности на нетрадиционалан начин, у комбинацији са осталим невојним садржајима иза којих стоји држава. Наравно, то не значи да хибридно ратовање не користе и други актери, који представљају недржавне учеснике и слабију страну у сукобу.

Хибридност се односи на комбиновану примену конвенционалних и неконвенционалних војних и невојних метода и ирегуларних форми, при чему је нагласак на невојним средствима субверзивне природе, а коришћење војних ефектива је тајно и уздржано. Конвертовањем рата у хибридни рат минимизује се улога оружане борбе тако да она постаје само један од садржаја рата, отварајући просторе ка отежаном разликовању мира и рата. У основи, овај концепт подразумева комбиновану примену конвенционалних и неконвенционалних метода ратовања, унутра кога су неконвенционалне методе заступљеније. Концепт укључује ангажовање војних и невојних средстава државне моћи ради постизања циљева, при чему се стратешки ефекти примарно очекују од примене невојних инструмената. Наравно, спорни етички и нормативни аспект ангажовања снага не могу да буду раздвојени од мултиваријантног концепта хибридног рата.

Хибридни ратови чине да потенцијалну будућност стварају мултимодални ратови у оквиру којих сукобљене стране ангажују различита капацитете и на различите начине, у зависности од окружења, као и сопствених и могућности противника. Узимањем у обзир сваког облика силе, кроз потпунију интеграцију, хибридни рат креира снажну стратегијску синергију, захтевајући бољу координацију ангажованих ефектива, ширећи просторе непредвидљивости у погледу форме, места и интензитета. На тај начин он генерише флексибилније и покретљивије снаге и актуелизује значај људског фактора у односу на било који други. Хибридно ратовања снажно дезавуише традиционални концепт рата, сматрајући да сила никада није била једини инструмент за политичке консеквенце. Пресек војних и невојних инструмената моћи јесте најделотворнија форма моћи, као и обим и софистицираност.

Хибридно ратовање потврђује општи тренд ка пуној интеграцији војних и невојних инструмената државне моћи у достизању политичких циљева. Промене у структури оружаних снага, као и праксе њиховог глобалног деловања, указују на флексибилност и адаптивност као кључне факторе ефикасности оружаних снага. Такође, још значајнији је став да савремено ратовање није само ангажман војника, већ и специјално обучених људи, плаћеника, као и специјализованих приватних компанија.

\section{АКТУЕЛНОСТ КЛАСИЧНЕ ВОЈНЕ МИСЛИ}

Парадигматске промене у физиономији оружаних сукоба стављају класичну стратешку мисао и праксу вођења рата на нимало лака искушења. Непрестана трансформација чини рат тешко упоредивим са било којим ранијим вођеним 
оружаним сукобом у политичкој историји света. ${ }^{11}$ Да ли ова специфична и садржајно и методски „неухватљива“ врста ратовања отвара пут за редефинисање класичног приступа рату? Постоји дилема да ли рат какав смо знали и даље постоји. За многе је концепт рата застарео и због тога је оправдана дистинкција између ратова у прошлости и савремених ратова. За неке ауторе је та разлика фундаментална. ${ }^{12}$

Несумњиво је да глобални процеси дају нове димензије рату, чинећи га опаснијим. ${ }^{13}$ Да ли ти процеси мењају природу рата? Да ли се природа рата мења или је она јединствена? Шта је права природа савремених ратова? Односно, да ли је традиционални концепт рата превазиђен? Да ли је Клаузевицева теорија валидна и данас? Рат постаје мање јасно дефинисан у међународном праву.

Мишљења су оштро супротстављена. За једне рат тако задобија чудне карактеристике, почев од тога да више није наставак политике, већ да иза рата стоји култура, да држава није главни протагониста ратовања, као и то да савремени ратови немају јасан крај, па војске морају све чешће да одбацују класичну дефиницију победе. Нови ратови, у чијој су основи политика идентитета и децентрализација насиља, заменили су старе ратове. ${ }^{14}$ Истовремено, други сматрају да нема ничег новог у ратовима 21. века. За оне који заступају традицоналистичко теоријско становиште, у природи рата се ништа драматично није десило, што значи да се мења карактер рата, али да природа рата одолева. 15

Наравно да би се идентификовало да ли се и колико рат изменио, важно је да се зна шта је то рат. Једна од главних тешкоћа савремених међународних односа јесте то што се не зна јесте, а шта није рат. Наглашена комплексност и широк спектар различитих манифестација рата значајно отежава његово дефинисање, а тренд непрестаног ширења дефиниције рата потискује суштинска одређења савременог појма рата. Последице такве конфузије су апсурдне. ${ }^{16}$ Таква ситуација додатно заоштрава потребу да се најпре мора знати шта је рат. Без одговора на ово питање, није могуће у потпуности одговорити и на оно - како се то рат мења?

Несумњиво, појам модерног рата је настао након Вестфалског мира, који је успоставио примат уједињене државне моћи и трајно позиционирање масовних стајаћих војски. ${ }^{17}$ Вестфалски мир, којим су 1648. године окончани тридесетогодишњи верски сукоби у Европи, отворио је просторе да ратови буду примарно утемељени у жељи националних држава да јачају своју спољну

\footnotetext{
11 Кристофер Кокер, Филозофи варвари, Завод за уџбенике, Београд, 2012, стр. 17.

12 Мери Калдор, Стари и нови ратови - организовано насиље у глобализованој ери, Београдски круг, Београд, 2005.

${ }^{13}$ Antulio J. Echevarria II, „Globalization and the Nature of War“, March, 2003.

14 Мери Калдор, исто.

15 Steven Metz, Phillip Cuccia, « Defininig War for the 21 ${ }^{\text {st }}$ Century», Strategic Studies Institute, US Army War College, 2010.

${ }^{16}$ Hew Strachan, „The Changing Character of War“, The Graduate Institute of International Relations, Geneva, 2006, p. 2.

17 Hew Strachan, The Changin Character of War, p. 1.
} 
безбедност или да увећавају своје територије на рачун других. На тај начин рат је постао међудржавни сукоб, а новоустановљени међународни поредак, који је трајао наредних неколико векова, био је резултат државне монополизације рата, имајући у виду чињеницу да се држава карактерисала монополом силе и значајно се дефинисала способношћу ратовања. 18

У основи модерног појма рата јесте општа сагласност да он представља најдрастичнији друштвени сукоб. Исто тако, рат је институционализована примена насиља, почива на конфликту, а елемент реципроцитета је критичан за сваку дефиницију рата. Рат претпоставља одређени ниво интензитета и трајања борбе, а онај који се бори, не чин то приватно, већ у служби државе, јер персонално ратовање није рат. Такође, рат није самом себи сврха, он има циљ који је политички детерминисан.

Наведени ставови чине суштину Клаузевицеве теорије, која представља основу класичне војне мисли чију оригиналност је тешко порећи. Истовремено, Клаузевицева теорија је и данас валидна. ${ }^{19}$ Клаузевиц је посебно оригиналан у дискусији о рату и његовој природи, односу између рата и политике. Тешко се може оспорити његово учења о објективној и субјективној природи рата, о тринитној природи рата, посебно о односу између рата и политике. Универзално су важеће Калузевицови закључци о фрикцији, случајности и непредвидивости у рату, као и ставови о валидности одређених стратегијских принципа или концепата, као што су центар гравитације и релативна надмоћ одбране. Такође, меродавно је његово истраживање и закључци о улози стратегије анализе на обједињавању циљева и средстава као важним конституентима рата.

Калузевиц је јасан, природа рата, упркос његовом еволуирајућем карактеру, је универзалана и безвремена. Он прави јасну разлика у поимању природе рата, као вечно датих сила које га трајно конституишу, и карактера као појавних, па према томе и променљивих аспеката у природи рата. Другим речима, природа је у основи оног што је суштинско и непроменљиво, а карактер представља манифестацију која се мења у складу са околностима. У природи рата је да се конкретизује у мноштву различитих облика, али природа рата се никада не мења, a карактер рата је актуелизација његове природе. ${ }^{20}$ Дакле, Клаузевицево мишљење, чија логичка утемељеност следи однос суштине и форме, и која се не може оспорити, јесте да рат има природу која се с временом не мења и карактер који се с временом мења. 21

Такође, Клаузевицев став о дуалној природи рата, односно став о објективној и субјективној природи рата, универзално је важећи. Иако ратови имају широк дијапазон различитих форми, они имају објективне карактеристике, као што су непријатељство, шанса и циљ, који доприносе универзалности рата коју

\footnotetext{
18 Carl Von Clausewitz, On War, Princeton University Press, USA, 1989.

${ }^{19}$ Antulio J. Echevaria II, Clausewitz Contemporary War.

${ }^{20}$ Кристофер Кокер, оп. цит., стр. 19.

${ }^{21}$ Исто, стр. 17.
} 
карактерише насиље, опасност, фрикција, неизвесност, физички напор. Ове карактеристике стално варирају у релативном значају и нивоу интензитета, а присутне су у ратовима антике колико и у савременим ратовима. Наравно, објективна природа је она која је есенцијална, перманентна и непроменљива у односу на време и средину његове актуелизације.22 Тако су насиље, фрикција, случајност и неизвесност заједнички свим ратовима, јер представљају стално присутне силе у природи рата. Субјективна природа рата, која подразумева војне снаге, доктрине, наоружање и окружење чине сваки рат јединственим. Субјективна природа је склона променама и на тај начин конституише карактер сваког рата понаособ.

Размишљања о рату, као и о политици и насиљу као суштинском одређењу рата сматрају се Клаузевицевим највећим доприносом војној мисли. Наглашавањем виталног значаја односа између рата и политике, он је оружани конфликт сместио унутар одговарајућег политичког миљеа, тврдећи да рат никада није изван тог миљеа. ${ }^{23}$ Политичке активности представљају оно што у свим случајевима даје подстицај конфликту, а војни циљеви су обликовани политиком и могу да буду реализовани уколико то политички услови дозвољавају. Политички детерминизам рата значи да политика увек има примат у управљању ратом, одређујући шта сила у постојећим политичким условима може да уради у служби политике.

Рат је чин насиља, а оно је у средишту Клаузевицеве тринитне природе рата. Управо зато се Клаузевицев систем мора посматрати као борбеноцентрични систем, у коме је борба највиши закон рата. ${ }^{24}$ Борбеноцентрична теорија рата наглашава значај битке, императив деструкције, односно борба је суштина рата. Ниво, интензитет и истрајавање на насиљу су различити од рата до рата, али насиље је још увек у основи избора средстава у сваком рату. Суштина рата је остала иста, дакле, политичка и насилна, мења се само његова форма сходно променама у окружењу. ${ }^{25}$ Савремени оружани сукоби се најзначајније легитимишу насиљем, што уверљиво потврђују размере деструкције које их прате, без обзира на то да ли је реч о конвенционалном, асиметричном или хибридном оружаном сукобу.

Тројствена природа рата такође спада у ред идеја које су Клаузевица сврстале у утемељиваче класичне стратегијске мисли. Клаузевиц тврди да рат обликују следеће главне силе: непријатељство, шанса, вероватноћа и разум. Наведене појаве чине стално присутне силе у природи рата. Прва своје извориште има у народу, друга припада војсци и војсковођи, а трећа припада држави и политици. Тако према Клаузевицу главни актери тројне природе рат јесу: народ, војска и

\footnotetext{
22 Милинко Врачар, „Физиономија рата у постмодерни: Студија случаја сиријског оружаног сукоба“ Међународни проблеми 4/2019.

${ }^{23}$ Antulio J. Echevaria II, Clausewitz Cotemporary War, Oxford University Press 2007

${ }^{24}$ Исто, стр. 6.

${ }^{25}$ Antulio J. Echevarria II, Clausewitz Contemporary War, p. 4
} 
држава. У анализи државе, војске и народа Клаузевиц истиче да су они неодвојиви од политичких активности, односно да политика представља снагу која обликује кључне конституенте рата. На тај начин политика постаје детерминистичка снага која суштински обликује карактер рата. ${ }^{26}$ Односно, рат има инструменталну природу, народ је основа нарастајућих непријатељстава, а деловање војске је повезано са бројним случајностима и неизвесностима. Кореспонденција рата и политике и инструментална природа рата остају трајно коректне. Рат остаје најутицајнији политички инструмент јер се у рату примењује организовано насиље ради постизања политичких циљева. Наглашавајући витални значај рата за политику, Клаузевиц оружани конфликт смешта унутар политичког миљеа. Ратови, укључујући савремен ратове, никада се не догађају изван тог миљеа. 27

Иако је наведена Клузевицева анализа тројне природе рата била посебно на удару заговорника идеје о новим ратовима, пре свега због нетрадиционалних оружаних сукоба, логички конзистентна анализа тешко може оспорити њихову ваљаност. Наиме, и савремени оружани нерегуларни ратови поседују тројствену природу, јер су то одређења која су иманентна природи рата. Иако иза таквих ратова не стоји држава као најорганизованији израз политичког организовања, актери таквих ратова своју виталност темеље на мање или више организованој војној сили и установљеној политичкој хијерархији, а истовремену имају подршку идејно блиских етничких и верских заједница. Исто тако, асиметрични, ирегуларни ратови или хибридни ратови наставак су политичких амбиција и идеолошких стремљења верских, етничких или неких других покрета. Дакле, савремени ратови не доводе у питање став о тројственој природи рата. Зато тешко могу бити одржива мишљења да су политички разлози престали да буду кључни покретачи ратова, већ да су генератори ратова постали идентитет, правда, цивилизацијска особеност, или да је рат одувек био одраз културе, а не политике. ${ }^{28}$ Јасно је да су наведени разлози савремених ратова по својој природи дубоко политички, без обзира на то што идејни фактори чине њихов преовлађујући гравитациони центар. Та чињеница не доводи у питање Клаузевицев став да је рат наставак политике другим средствима, чиме га суштински, чврсто и прецизно смешта унутар политике, односно, прецизније, међународне политике. ${ }^{29}$

Клаузевицева дефиниција стратегије, која подразумева ангажовање средстава за дефинисане циљева рата, такође је валидна. Она повезује циљеве и средства, што је фундаментални однос који обједињује активности на свим нивоима ратовања. Јасно је да у поимању стратегије Клаузевиц апострофира инструменталност војне силе, наглашавајући чињеницу да се стратегија односи на коришћење силе или

\footnotetext{
${ }^{26}$ Carl Fon Clausewitz , On War, Princeton University Press, USA, 1989.

27 Antulio J. Echevaria II, Clausewitz Cotemporary War.

28 John Keegan, A History of Warfare, Vintage Books, New York, 1994, pp3-60.

${ }^{29}$ Antulio J. Echevarria II, Clausewitz Contemporary War, p.4 .
} 
претњу силом ради достизања циљева политике. ${ }^{30}$ Када је реч о Клаузевицевим стратегијским принципима, они су данас ближи појму оперативне вештине него стратегији. Иако их многи сматрају валидним, они су примеренији линеарном него нелинеарном окружењу. Остаје као неспорно да стратегијска димензија међународне политике јесте главни наратив за разумевање смера и динамике међународних односа. Зато проучавање историје стратегије обезбеђује валидан и суштински значајан оквир за разумевање курса светске политике. ${ }^{31}$

\section{ЗАКЉУЧАК}

Бројни глобални процеси учинили су елемент непријатељства критичним и тако креирали глобални социјални миље за широк спектар неконвенционалних и нових манифестација рата. Савремени оружани сукоби постали су комплекснији, свеобухватнији и у бројним аспектима различити од ратова вођених у ранијим периодима. Али природа рата, његова логика, остала је непромењена. Рат 21. века остаје суштински клаузевицевски по природи. Он остаје акт физичке силе који је одлучујући политички профилисан. Актуелни глобални процеси оснажили су улогу коју политика игра у рату, учинивши ту кореспонденцију непорецивом, технолошки прогрес проширио је садржаје и домене испољавања конфликта у савременим оружаним сукобима.

Та чињеница не умањује потребу трагања за начинима за превазилажење ограничења са којим се сусреће класична савремена војна мисао и пракса нових оружаних сукоба, посебно ако се има у виду да рат остаје најутицајнији инструмент у савременим међународним односима. Управо зато, потреба да се проблематизују многобројна питања у теоријској перцепцији рата отвара просторе за нова сагледавања савремених оружаних сукоба, као и потребу да класична стратегијска мисао укалкулише теоријске и практичне иновације када је реч о савременим оружаним сукобима и тако даље оснажује своју релевантност.

\section{ЛИТЕРАТУРА}

1. Clausewitz Von Carl, On War, Princeton University Press, USA, 1989.

2. Dugin Aleksandar, Savin Leonid, Mrežni ratovi, Avala pres, d.o.o., Beograd, 2018.

3. Echevarria J.Antulio II, „Globalization and the Nature of War”, March, 2003.

4. Echevarria J. Antulio II, Clausewitz Contemporary War, Oxford University Press, New York, 2007.

5. Gray S. Colin, “War, Peace and International Relations”, Rutledge, London, New York, 2007.

6. Keegan, John, A History of Warfare, Vintage Books, New York, 1994.

30 Colin S. Gray, War, Peace and International Relations, Rutledge, New York, 2007.

${ }^{31}$ Colin S. Gray, ucmo. 
7. Korać, Srđan, Disciplinsko ratovanje $u$ doba dronova $i$ robota, Institut za međunarodnu politiku i privredu, Beograd, 2019.

8. Lawrence Frieedman, The Future of War, A History, BBS Public Affairs, New York, 2017.

9. Metz Steven, Cuccia Phillip, „Defininig War for the 21 st Century“, Strategic Studies Institute, US Army War College, 2010.

10. Reichborn-Kjennerud Erik, Cullen Patrick, „What is Hybrid Warfare?", Policy Brief, 1 /2016.

11. Savin Leonid, Koučing ratovanja, Beograd, 2019.

12. Smith Rupert, The Utility of Force The Art of War in the Modern World, A. Konpf Book, New York, 2007.

13. Strachan Hew, "The Changing Character of War", The Graduate Institute of International Relations, Geneva, 2006.

14. Strachan Hew, The Changin Character of War, Europaeum, Oxford, 2007.

15. Врачар Милинко, „Физиономија рата у постмодерни: Студија случаја сиријског оружаног сукоба“, Међународни проблеми 4/2019, str. 447-475.

16. Калдор Мери, Стари и нови ратови - организовано насиље у глобализованој ери, Београдски круг, Београд, 2005.

17. Кревелд Ван, Мартин, Трансформација рата, ЈП, Службени гласник, Факултет безбедности, Београд, 2010.

18. Кристофер, Кокер, Филозофи варвари, Завод за уџбенике, Београд, 2012.

19. Стојановић Станислав, Благојевић Вељко, Суботић Милован, Милосављевић Бранислав и Миленковић Милош, Асиметрично угрожавање безбедности на примеру Југоисточне Европе, Медија Центар, Београд, 2019.

20. Стојановић Станислав, Ђурић, Атанасиевски Ксенија, „Дефицити и ограничења глобалног управљања“, Српска политичка мисао, Београд, 2/2016.

21. Тофлер Алвин, Тофлер Хајди, Рат и Анти рат, Паидеа, Београд, 1998.

\section{WARS OF THE XXI CENTURY AND CLASSICAL STRATEGIC THOUGHT}

The dramatic changes taking place in the theory and practice of modern armed conflicts, especially their complexity and wide range of manifestations and their increasingly pronounced asymmetric, hybrid and network-centric character, suggest that these are new wars, different from all previous ones. The most radical expressions of the transformation of war initiated by changes in post-industrial reality are the idea of a network based on the coevolution of information technology, economics, business processes and organization. The network-centric paradigm is primarily focused on exploiting the range of technological superiority, it shifts the center of modern armed conflicts beyond the physical domain, and the functioning of combat formations becomes based on the principles of speed and selfsynchronization, which allow to see, orient and act before opponents. At the same time, asymmetry, as the most significant feature of changes in the political, economic and social milieu of modern people's lives, is also a paradigmatic feature of the modern security environment and armed conflicts that are taking place today. The increasingly pronounced antisocial context of global processes, above all their pronounced transnational character, 
forms the social framework for the emergence of strong and unpredictable asymmetric threats to the security of modern societies. Of course, the continuity of realpolitik patterns in international politics and open geopolitical competition, and even more often covert actions of the most powerful countries in the world, as well as other non-state actors, have intensified hybrid armed conflicts, whose confusing physiognomy emphasizes a synergistic approach to integrating all instruments of state power highlighting non-military and irregular content. This specific, substantively and methodologically elusive type of wars, especially when it comes to motives, goals and ways of acting, points to their grounding in their own strategic approach, putting the serious strategic thought and practice of warfare to serious tests. Numerous questions have been raised about the essence of wars and the ways in which they are fought, questioning the viability of some of the main postulates of classical strategic thought and Clausewitz as one of its most important founders. Without denying that the wars of the 21st century are authentic in many respects, the starting theoretical position of the authors of this paper is that classical strategic thought is still a relevant and valid theory and that it is indispensable in creating strategic capabilities of modern civilian leaders and military strategists.

Keywords: new wars, network-centric war, asymmetric war, classical strategy 